\title{
Effect of Intercropping Cowpea (Vigna unguiculata L.) with Teosinte (Zea mexicana Schrad ) on Forage Yield Productivity and Its Quality
}

\author{
Azza Kh. Salem ${ }^{(1) \#, ~ F a d i a ~ M . ~ S u l t a n ~}{ }^{(1)}$, K.A. El- Douby ${ }^{(2)}$ \\ ${ }^{(1)}$ Forage Crops Research Department, Field Crops Research Institute, Agricultural \\ Research Center (ARC), Giza, Egypt; (2) Crop Intensification Research Department, \\ Field Crops Research Institute, Agricultural Research Center (ARC), Giza, Egypt.
}

\begin{abstract}
$\mathbf{T}$ WO FIELD experiments were carried out at Giza Agricultural Research Station $\left(30^{\circ} 02^{\prime}\right.$ $\mathrm{N}$ latitude and $31^{\circ} 13^{\prime} \mathrm{E}$ longitude, altitude $22.50 \mathrm{~m}$ above sea level), Egypt, during 2017 and 2018 seasons to investigate the effect of three intercropping patterns of cowpea (Vigna unguiculata L.) with teosinte (Zea mexicana Schrad) (1- On the other side of teosinte ridges, $1: 1$ and $2: 2$ in alternating ridges) and three seeding rates, $(50 \%+50 \%, 75 \%+50 \%$ and $50 \%$ $+75 \%$ ) teosinte/cowpea of its pure stand on forage yield and its quality. A split plot design with three replicates was used. The results could be summarized as follows:-

- Intercropping pattern of 2:2 recorded the highest values for total fresh and dry forage yields whereas cowpea intercropped on the other side gave the lowest values in both seasons. Seeding rate of $75 \%+50 \%$ teosinte/cowpea recorded the highest values for total fresh and dry forage yields in both seasons. Intercropping pattern $2: 2$ with $75 \%$ teosinte $+50 \%$ cowpea gave the highest value of totally fresh and dry yields. Whereas, planting cowpea on the other side with $50 \%$ seeding rates of both crops, gave the lowest values in both seasons.

- Crude protein and digestible protein percentages, crude protein and digestible protein yields fed ${ }^{-1}$ were increased by different intercropping patterns. Seeding rates and the interaction between them compared with teosinte pure stand in both seasons, whereas fiber percentage behaved opposite trend in both season.

- Land equivalent ratio (LER) and relative crowding coefficient recorded the highest values by the interaction between $2: 2$ ridges and $75 \%$ teosinte $+50 \%$ cowpea seeding rates of its pure stands in both seasons. Teosinte was dominant crop in 6 out of 9 treatments in both seasons.

- It could be concluded that $15 \mathrm{~kg}$ teosinte $+10 \mathrm{~kg}$ cowpea and 2:2 intercropping pattern in alternate to obtain the highest mixture yield and quality.
\end{abstract}

Keywords: Cowpea (Vigna unguiculata L.), Toesinte (Zea mexicana Schrad ), Seeding rate, Intercropping patterns.

\section{Introduction}

Teosinte (Zea mexicana Schrad L.) is one of the most important summer forage crops which closely related to maize in most allometric trait. It has the advantage of tillering and regeneration as a fodder crop (Lal et al., 1980). Sarhan \& Atia (2000) revealed that teosinte+cowpea mixture was superior to monocropping with an increase in forage and protein yields. Mixed intercrop was used to investigate on forage yield as well as the effect of intercropping on maize forage quality. Abd El-Shafy (2002) reported that total fresh and dry forage yields when teosinte intercropped with guar were significantly higher than those obtained from guar monoculture, but lower than those obtained from teosinte sole cropping. Hassan (2003) revealed that guar plant height significantly decreased due to planting in association with fodder maize. Thus, guar plants in pure stand

"Corresponding author email: azzakhali1106@yahoo.com

DOI: 10.21608/agro.2019.11752.1161

C2019 National Information and Documentation Center (NIDOC) 
were the highest as compared with those in mixed cropping. Zeidan et al. (2003) stated that fodder maize sole planting gave higher fresh and dry forage yields than either cowpea or guar whereas, planting cowpea in pure stand gave higher protein yield/fed when compared with fodder maize and guar. Intercropping including legumes is known to enhance forage crude protein concentration compared with cereal sole cropping and to use resources more efficiently (Papastylianou, 2004). Abd El-Shafy et al. (2009) concluded that forage mixture were of more crude protein (CP) content than teosinte but less than cowpea in its pure stand, while crude fiber (CF) content was less in than teosinte and more in cowpea pure stands. Digestible protein (DP) content was more in cowpea and less in teosinte pure stands. The intercropping pattern of 2:2 gave the highest yield advantage and caused an increase in land usage of $36 \%$ and $34 \%$ in the two respective summer seasons. Dahmardeh et al. (2009) concluded that intercropping of maize and cowpea resulted in more digestible dry matter and also crude protein content than maize sole cropping. Hamdollah \& Ahmad (2009) showed that intercropping systems had a significant effect on forage dry weight, where dry matter yield was increased by intercropping as compared with maize and cowpea sole crops. Javanmard et al. (2009) worked on intercropping of maize with different legumes and indicated that dry matter yield and crude protein yield of forage increased by all intercropping compositions as compared with maize monoculture. Maurice et al. (2010) reported that cowpea/maize intercropping reduced the yield of cowpea due the maize canopy that interferes with light penetration. Sharawy et al. (2011) indicated that plant height of teosinte, cowpea and guar decreased significantly by intercropping compared with their pure stands. Total fresh and dry forage yields were significantly reduced by intercropping teosinte with cowpea or guar compared with teosinte as a sole crop. Eskadari (2012) reported that the intercropping was attributed to higher forage production by intercrops and also protein content. Reza (2012) indicated that the crude protein and dry matter yields of sorghum (Sorghum bicolor L. Moench) increased with legumes compared with sorghum monoculture. Abraha (2013) found that the higher Land equivalent ratio (LER) was obtained from cowpea intercrops (1.71) which indicates the intercropping of maize-cowpea was advantageous than mono crop maize. Hassan et al. (2017) resulted that the planting of grasses intercropped with legumes caused increase in total land equivalent ratio (LER) for the total three cuts of both crops which was greater than one in all intercropping treatments.

So, this present experiment was aimed to investigate the effect of some intercropping patterns and seeding rates of teosinte and cowpea for obtaining a good fodder yield of improved quality, an accurate balance of teosinte and cowpea in a mixture is very essential as well as land use efficiency.

\section{Materials and Methods}

A field experiment was conducted through 2017 and 2018 seasons at Giza Experimental Research Station Farm $\left(30^{\circ} 02^{\prime} \mathrm{N}\right.$ latitude and $31^{\circ}$ $13^{\prime}$ E longitude, altitude $22.50 \mathrm{~m}$ above sea level). Agricultural Research Center to study the effect of three intercropping cowpea (Vigna unguiculata (L.) with teosinte (Zea mexicana Schrad) on forage yield productivity and its quality.

The treatments were as follows:

Intercropping patterns for cowpea with teosinte

1- Intercropping cowpea on the other side of teosinte ridges

2- Intercropping cowpea on one ridge cowpea: one ridge teosinte in alternate

3- Intercropping cowpea on two ridges cowpea: two ridges tosinte in alternate.

Three seeding rates of both components as follows:

1- $50 \%\left(10 \mathrm{~kg} / \mathrm{fed}^{-1}\right)$ teosinte $+50 \%(10 \mathrm{~kg} /$ $\left.\mathrm{fed}^{-1}\right)$ cowpea

2- $75 \%\left(15 \mathrm{~kg} / \mathrm{fed}^{-1}\right)$ teosinte $+50 \%(10 \mathrm{~kg} /$ $\left.\mathrm{fed}^{-1}\right)$ cowpea

3- 50\% (10kg/fed $\left.{ }^{-1}\right)$ teosinte $+75 \% \quad(15 \mathrm{~kg} /$ $\left.\mathrm{fed}^{-1}\right)$ cowpea of its pure stands. Beside of pure stand teosinte and cowpea as recommended $\left(20 \mathrm{~kg} / \mathrm{fed}^{-1}\right)$.

The experimental design was factorial experiment conducted in a split-plot design with three replications was used. Intercropping patterns were allocated at main plots and seeding rates were arranged in sub-plots. Sub-plot was $14.4 \mathrm{~m}^{2}$ included 8 ridges $(0.6 \mathrm{~m}$ ridge width and ridge length was $3.0 \mathrm{~m}$ ).

Physical and chemical analysis of soil at Giza (average of the two seasons) was recorded in Table 1. 
TABLE 1. Some physical and chemical properties of the soil at the experimental site.

\begin{tabular}{lc}
\hline Soil fraction & Content\% \\
\hline Coarse sand & 2.91 \\
Find sand & 13.40 \\
Silt & 30.51 \\
Clay & 53.18 \\
Textural class & Clay \\
Soil chemical analyses & Content \\
Organic matter & $1.80 \%$ \\
Available N(KCl-extract) & $40.0 \mathrm{mg} \mathrm{kg}^{-1}$ \\
Available P(Na-bicarbonate -extract) & $19.0 \mathrm{mg} \mathrm{kg}^{-1}$ \\
Available K(NH4 a acetate extract) & $304 \mathrm{mg} \mathrm{kg}^{-1}$ \\
pH (1:2.5, soil: water extract) & 7.4 \\
\hline
\end{tabular}

The preceding crop for both seasons was wheat (Triticum aestivum L.). Sowing dates of both crops were at May15, 2017 and May 20, 2018 seasons. Experimental land was prepared by calcium superphosphate $\left(15.5 \% \mathrm{P}_{2} \mathrm{O}_{5}\right)$ was added before sowing at rate of $100 \mathrm{~kg} \mathrm{fad}^{-1}$., potassium sulphate $\left(48 \% \mathrm{~K}_{2} \mathrm{O}\right)$ was added at the rate of $50 \mathrm{~kg}$ fed $^{-1}$. and $75 \mathrm{~kg} \mathrm{~N} \mathrm{fed}^{-1}$, as urea $(46.5 \% \mathrm{~N})$ applied at three equal doses, i.e., at the first irrigation, after the $1^{\text {st }}$ and the $2^{\text {nd }}$ cut, respectively. The three cuts were taken in both seasons, the first cut was after 65 days of planting and the following cuts were 30 days intervals in both seasons.

At cutting time, plants of in sub-plots were cut from the four inner ridges to determine the following parameters:

\section{Growth character}

Plant height $(\mathrm{cm})$ for each sole crop as well as for both components of intercropped.

\section{Forage yield}

Fresh forage yield (ton fed $^{-1}$ ): Subplots were hand clipped and weighed in $\mathrm{kg}$ subplot ${ }^{-1}$, then adjusted into ton $\mathrm{fed}^{-1}$

Dry forage yield (ton fed $^{-1}$ ) was calculated by multiplying fresh forage yield (ton $/ \mathrm{fed}^{-1}$ ) X dry matter percentage (DM\%) (Norman \& Jarvis, 1975).

Crude protein yield $\left(\mathrm{kg} \mathrm{fed}^{-1}\right)$ was calculated as: Dry forage yield X Crude protein percentage in forage.

Digestible protein yield $\left(\mathrm{kg} \mathrm{fed}^{-1}\right)$ was calculated as: Dry forage yield $\mathrm{X}$ digestible protein percentage.

\section{Chemical analysis}

Plants samples of each cut in both years were analyzed in the Forage Crops Research Dept. Lab at Giza to determine :

1-Dry matter \%: Fresh samples (250gm) were dried at $70{ }^{\circ} \mathrm{C}$ to a constant weight in an electrical oven and dry matter\% was calculated as: (Weight of dry plants)/(Weight of fresh plants) X100

2- Crude protein percentage (CP \%): $\mathrm{N}$ content in forage was determined by the Microkelahl method (A.O.A.C., 2000) and the crude protein \% was obtained by multiplying $\mathrm{N}$ content by a factor of 6.25 (Hymowitz et al., 1972).

3- Digestible crude protein (DCP \%) was calculated according to the equation of Churach $(1979)$ as: $(\mathrm{DCP} \%)=(\mathrm{CP} \% \mathrm{X} 0.929)-3.48$.

4- Crude fiber percentage (CF \%): Forage samples were digested in sulphuric acid and sodium hydroxide $(1.25 \mathrm{~N})$, and crude fiber was determined by the method of A.O.A.C. (2000).

\section{Competitive relationships}

Land equivalent ratio (LER)

It was calculated according to Willey (1979):

$$
\mathrm{LER}=\frac{\mathrm{y}_{\mathrm{ab}}}{\mathrm{y}_{\mathrm{aa}}}+\frac{\mathrm{y}_{\mathrm{ba}}}{\mathrm{y}_{\mathrm{bb}}}
$$

where : $\mathrm{Y}_{\mathrm{ab}}=$ Yield of intercrop a (teosinte) with $\mathrm{b}$ (cowpea), $Y_{b a}=$ Yield of intercrop b (cowpea). with a (teosinte), $Y_{a a}=$ Pure stand yield of a (teosinte), $\mathrm{Y}_{\mathrm{bb}}=$ Pure stand yield of $\mathrm{b}$ (cowpea).

\section{Relative crowding coefficient (RCC)}

Relative crowding coefficient was calculated according to De-Wit (1960) by the following formula:

$$
K_{a b}=\frac{Y_{a b} \times Z_{b a}}{\left(Y_{a a}-Y_{a b}\right) \times Z_{a b}} \quad K_{b a}=\frac{Y_{b a} X Z_{a b}}{\left(Y_{b b}-Y_{b a}\right) \times Z_{b a}}
$$

where: $\mathrm{Z}_{\mathrm{ab}} \%=$ Area occupied by teosinte mixture, $\mathrm{Z}_{\mathrm{ba}} \%=$ Area occupied by crops cowpea mixture, $\mathrm{K}=\mathrm{K}_{\mathrm{ab}} \mathrm{X} \mathrm{K}_{\mathrm{ba}}$

Aggressivity (Agg): (Mc-Gilchrist, 1965)

It was measured by the following formula: 
Agg. $A=A 1-A 2$ for teosinte intercropped, A2A1for cowpea intercropped.

Agg. teosinte $=\frac{Y_{a b}}{Y_{a a} X Z_{a b} \%}-\frac{Y b a}{Y_{b b} X Z_{b a} \%}$

Agg. cowpea intercropped $=\frac{Y_{b a}}{Y_{b b} X Z_{b a} \%}-\frac{Y_{a b}}{Y_{a a} X Z_{a b} \%}$

\section{Statistical analysis}

The obtained data were statistically analyzed according to Steel et al. (1980). The assumption of all obtained results was statistically analyzed to compare the means through L.S.D. test at probability of 0.05 as described by Snedcor \& Cochran (1981).

\section{Results and Discussion}

\section{Plant height}

Effect of intercropping patterns

Data presented in Table 2 indicated that the plant height of teosinte or cowpea were significantly affected by intercropping patterns in both seasons. Plant heights of both components in monoculture recorded the highest values compared with intercropping patterns in both seasons. The intercropping pattern of 2:2 was a superior for plant heights of both crops in $1^{\text {st }}$ cut, $2^{\text {nd }}$ cut 2 and $3^{\text {rd }}$ cut followed by 1:1 intercropping patterns, but intercropping cowpea on the other side of ridge showed the lowest values in both seasons. This results may be due to the intercropping pattern of 2:2 was able to complement each other in growth integration and reduce intra-specific competition between teosinte and cowpea plants than other intercropping patterns. Similar results were obtained by Abd EL-Shafy (2002) and Sharawy et al. (2011).

\section{Effect of seeding rates}

Results revealed that seeding rates significantly affected on plant heights of teosinte and cowpea in both seasons as shown in Table 2. Data revealed that $50 \%+50 \%$ seeding rates for both crops of its pure stands recorded the highest values followed by $50 \%$ teosinte $+75 \%$ cowpea and the lowest values were obtained at $75 \%$ teosinte $+50 \%$ cowpea. This is completely true for cut 1 , cut 2 and cut 3 in both seasons. This results may be due to increasing plant population/unite area from 50 up to $75 \%$ of its pure stands either teosinte or cowpea increased competition (inter or intra-specific) for light, water and nutrients specially teosinte plants under
$75 \%$ teosinte $+50 \%$ cowpea. Similar results were obtained by Abd EL-Shafy et al. (2009).

\section{Interaction effects}

Data in Table 2 showed that plant height of teosinte or cowpea insignificantly affected by the interaction between intercropping patterns $\mathrm{X}$ seeding rates in both seasons.

\section{Fresh and dry forage yields}

\section{Effect of intercropping patterns}

Data showed that fresh and dry forage yields were significantly affected by different intercropping patterns in both seasons as shown in Table 3. The intercropping pattern of 2:2 was superior in fresh and dry forage yields production followed by $1: 1$ intercropping pattern and intercropping cowpea on the other side recorded the lowest value. This is completely true in the first and second seasons. Total forage behaved the same trend and recorded (34.72 and 34.41ton fed $\left.\mathrm{fe}^{-1}\right),(32.67$ and 30.94) and (31.36 and 29.58) for fresh forage yield (7.00 and 6.65), (6.67 and 6.42) and (6.41 and 5.95) for dry forage yield in the first and second seasons, respectively. Data revealed that $2^{\text {nd }}$ cut recorded the highest value of fresh and dry forage yields, followed by $1^{\text {st }}$ cut while the third cut gave the lowest one. Such trend could be explained by the limited growth behavior from sowing date to cutting time (65 days), where the plants establish their rooting system, whereas, during the growth period for the $2^{\text {nd }}$ cut, plants received more better and warmer condition to improve their vegetative growth which led to an increase in plant height growth. However plants at the $3^{\text {rd }}$ cut growing period tended to initiate flowering and the more warm environmental conditions at that period of growth cause and extra expenditure of energy in flowering and seed initiation as well as for respiration of plants rather than in vegetative growth (Abd EL-Shafy et al., 2009). Similar results Sarhan \& Attia (2000), Riza (2012) for fresh forage yield; and Dahmardeh et al. (2009) and Reza (2012) for dry forage yield.

\section{Seeding rates}

Data presented in Table 3 indicated that fresh and dry forage yields were significantly affected by seeding rates in both seasons except in $2^{\text {nd }}$ cut and $3^{\text {rd }}$ cut in the second seasons onley. Data revealed that $50 \%$ teosinte $+75 \%$ cowpea gave the highest value for fresh forage yield in both seasons at $1^{\text {st }}$ cut and $75 \%$ teosinte $+50 \%$ cowpea gave the highest value at $2^{\text {nd }}$ cut, $3^{\text {rd }}$ cut and total yield in both seasons; whereas $50 \%+50 \%$ seed rate of its 
pure stands showed the lowest values at three cuts and total yield in both seasons. Fresh yield was increased by increasing seeding rates of teosinte or cowpea and more increase with $75 \%$ teosinte $+50 \%$ cowpea. With respect to dry yield, data revealed that dry forage yield behaved the same trend of fresh forage yield in three cuts as well as total dry yield in both seasons as shown in Table 3. Seeding rate of $75 \%$ teosinte $+50 \%$ cowpea achieved the highest value for dry yield as a total yield of 7.12 and 6.50ton $\mathrm{fed}^{-1}$ in the first and second seasons, respectively, whereas $50 \%+50 \%$ produced the lowest values were 6.23 and 6.05 ton $^{-f^{-1}}$ in the first and second seasons, respectively. Similar results were coincided with those obtained by Papastylianou (2004) and Hamadollah \& Ahmed (2009) for fresh forage yield; Hassan et al. (2017) for dry forage yield.

\section{Interaction effects}

Data in Table 3 indicated that $2^{\text {nd }}$ cut in both seasons, $1^{\text {st }}$ cut, $3^{\text {rd }}$ cut and total yield of fresh forage in second season were significantly affected by the interaction between intercropping pattern with seeding rates. Also, data revealed that $3^{\text {rd }}$ cut in the first seasons, $1^{\text {st }}$ cut, $2^{\text {nd }}$ cut in the second seasons and total yield of dry forage in two seasons were significantly affected by the interaction between two factors under study. In general 2:2 intercropping pattern with seeding rate $75 \%$ teosinte $+50 \%$ cowpea superior for total in fresh and dry forage production which produced (37.17 and 35.75ton fed $^{-1}$ ) for fresh forage yield and (7.43 and 6.94ton fed $\left.^{-1}\right)$ for dry forage yield in the first and second seasons, respectively. Similar results were obtained by Sarhan \& Attia (2000) and Eskadari (2012) for fresh forage yield and Abd ELShafy (2002) and Javanmard et al. (2009) for dry forage yield.

\section{Chemical traits \\ Effect of intercropping patterns \\ Data in Table 4 indicated that different intercropping patterns significantly affected on three cuts as well as mean of crude protein $\%$ $(\mathrm{CP} \%)$, digestible crude protein \% $(\mathrm{DCP} \%)$ and crude fiber\% $\%(\mathrm{CF} \%)$ in both seasons, except mean of crude fiber in both seasons. Data revealed that cowpea pure stand was more $\mathrm{CP} \%$ and $\mathrm{DCP} \%$ compared with all intercropping patterns and teosinte pure stand in both seasons. Also, data revealed that the highest values of $\mathrm{CP} \%$ and $\mathrm{DCP} \%$ of intercropping patterns were recorded at 2:2 intercropping pattern as a mean in both seasons. On}

the other hand, the lowest values of these characters were showed when cowpea intercropped on the other side of teosinte ridges in both seasons. This result may be due to cowpea as a legume crop had more riches of protein content in its alternative 2:2 and in pure stand and this reflected that on $\mathrm{DCP} \%$ at different intercropping patterns.

Concerning $\mathrm{CF} \%$, data revealed that teosinte pure stand had more $\mathrm{CF} \%$ than cowpea pure stand and different intercropping patterns. Data revealed that $\mathrm{CF} \%$ all intercropping patterns behaved opposite trend of $\mathrm{CP} \%$ and DCP \% in both seasons. So, 2:2 intercropping pattern gave the lowest value for $\mathrm{CF} \%$ and the highest value was obtained when cowpea intercropped at the other side of teosinte ridges in both seasons. These results were obtained by Abd EL-Shafy et al. (2009) for CP\%, Dahmaradeh et al. (2009) for $\mathrm{CF} \%$ and Eskadari (2012) for DCP\%.

\section{Effect of seeding rates}

Data presented in Table 4 showed that three cuts and its average were significantly affected by seeding rates in both seasons except an average of $\mathrm{CF} \%$. Data revealed that $50 \%$ teosinte $+75 \%$ cowpea of its pure stands recorded the highest values for $\mathrm{CP} \%$ and $\mathrm{DCP} \%$ while it recorded the lowest value for $\mathrm{CF} \%$ in both seasons. on the other hand, 50\% teosinte $+50 \%$ cowpea showed the lowest values for $\mathrm{CP} \%$ and DCP \%; and the highest value for $\mathrm{CF} \%$ in both seasons. This result may be due to increase cowpea seeding rate from $50 \%$ to $75 \%$ increased $\%$ of CP and DCP $\%$ beside of reduce $\mathrm{CF} \%$ in dry forage yield because of cowpea more riches in $\mathrm{CP}$ content as shown at cowpea pure stand. Similar results were accorded with Eskadari (2012) and Reza (2012) for CP \%, Maurice et al. (2010) and Zeidan et al. (2003) for DCP \% as well as Abd EL-Shafy et al. (2009) for CF \%.

\section{Interaction effects}

Data presented in Table 4 indicated that the interaction between factors under study significantly affected on three cuts and its averages of $\mathrm{CP} \%$, DCP $\%$ and $\mathrm{CF} \%$ in $2^{\text {nd }}$ season only. Data revealed that increasing cowpea seeding rate from $50 \%$ to $75 \%$ with $50 \%$ teosinte under $2: 2$ intercropping pattern increased $\mathrm{CP} \%$ and $\mathrm{DCP} \%$ while reduced $\mathrm{CF} \%$ than other treatments.Similar results were obtained with Abraha (2013) for CP $\%$, Hamdollah \& Ahmed (2009) for DCP \% and Abd EL-Shafy (2002) and Abd EL-Shafy et al. (2009) for $\mathrm{CF} \%$. 


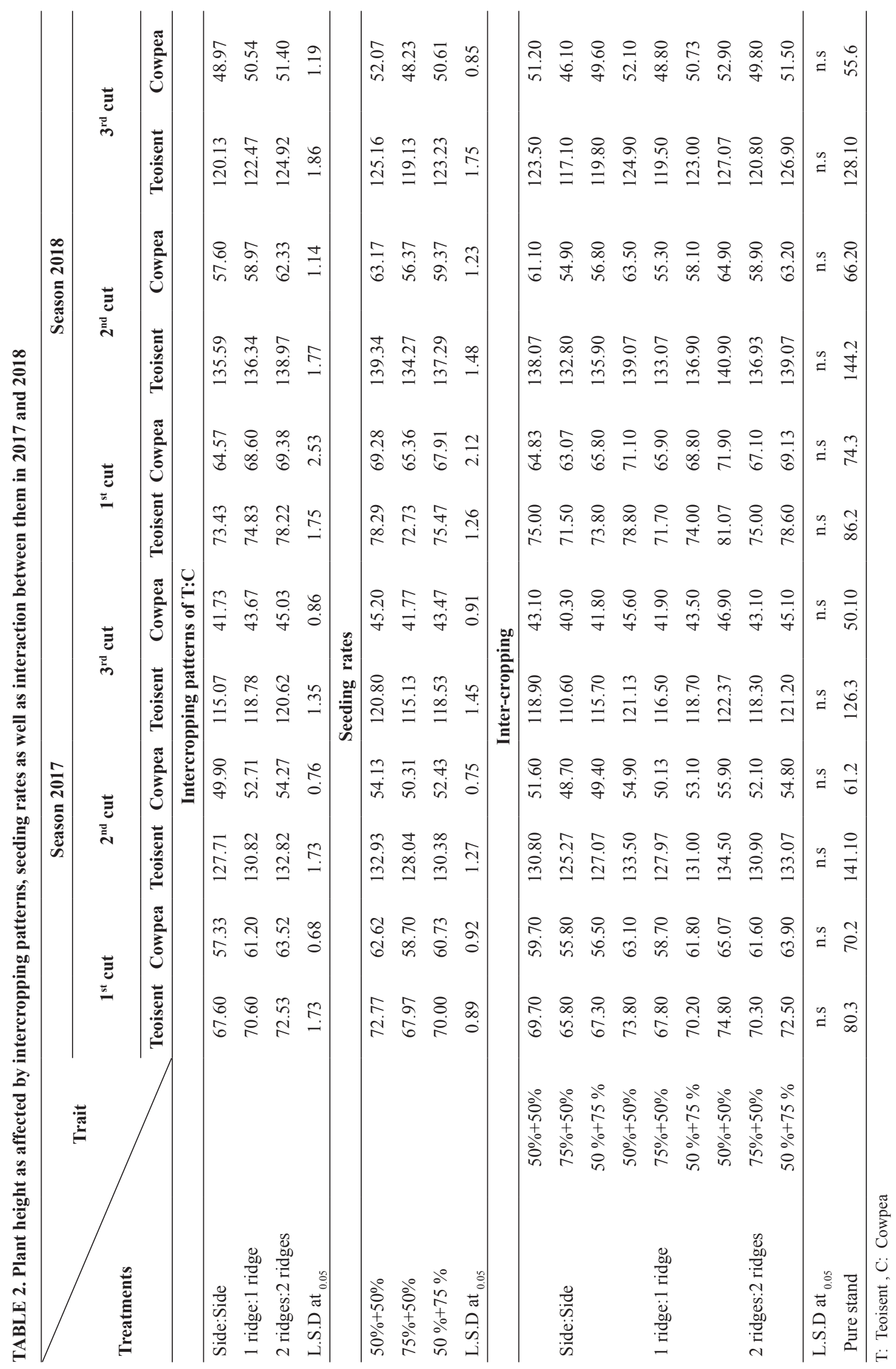

Egypt. J. Agron. 41, № .2 (2019) 


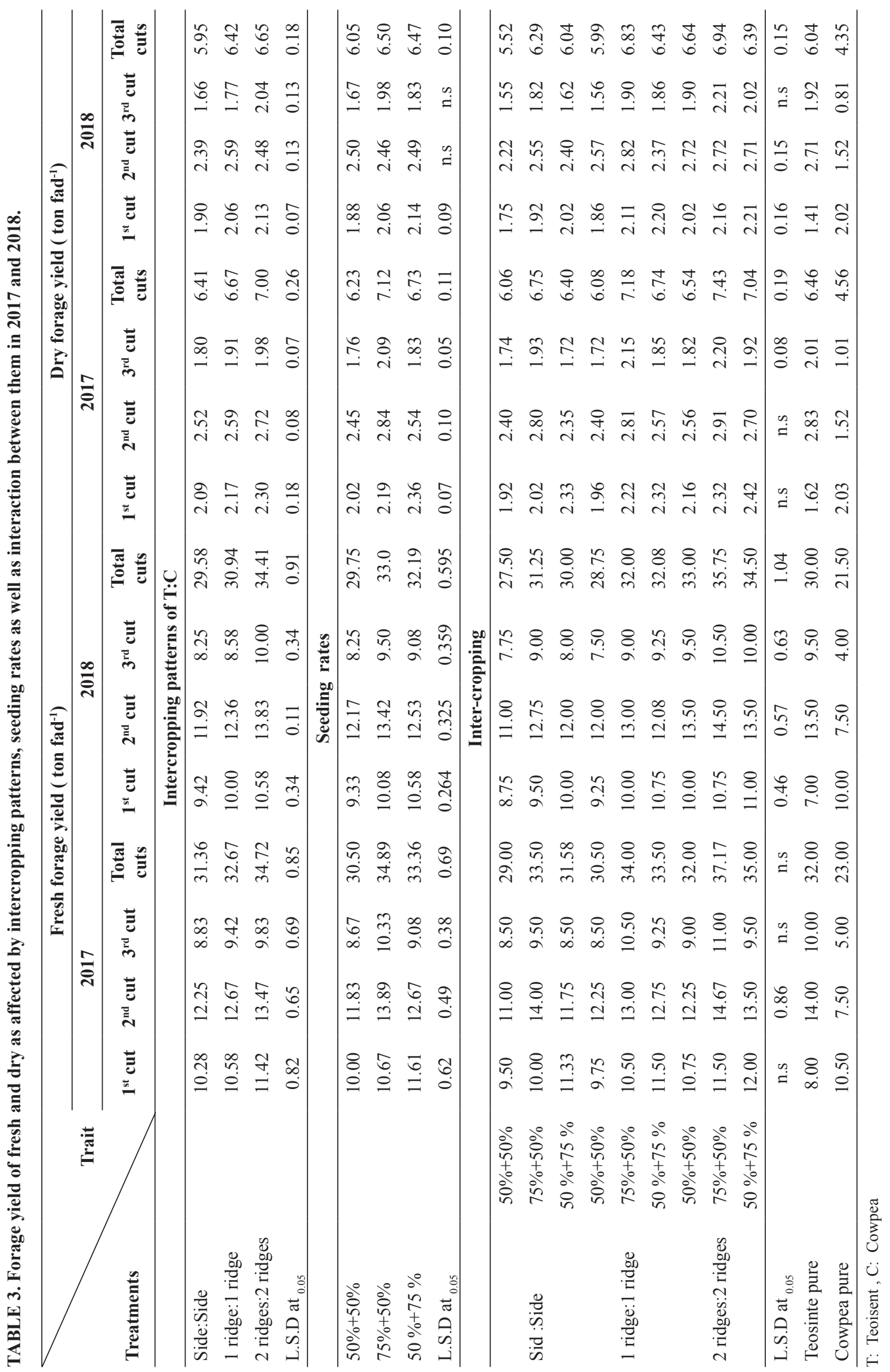




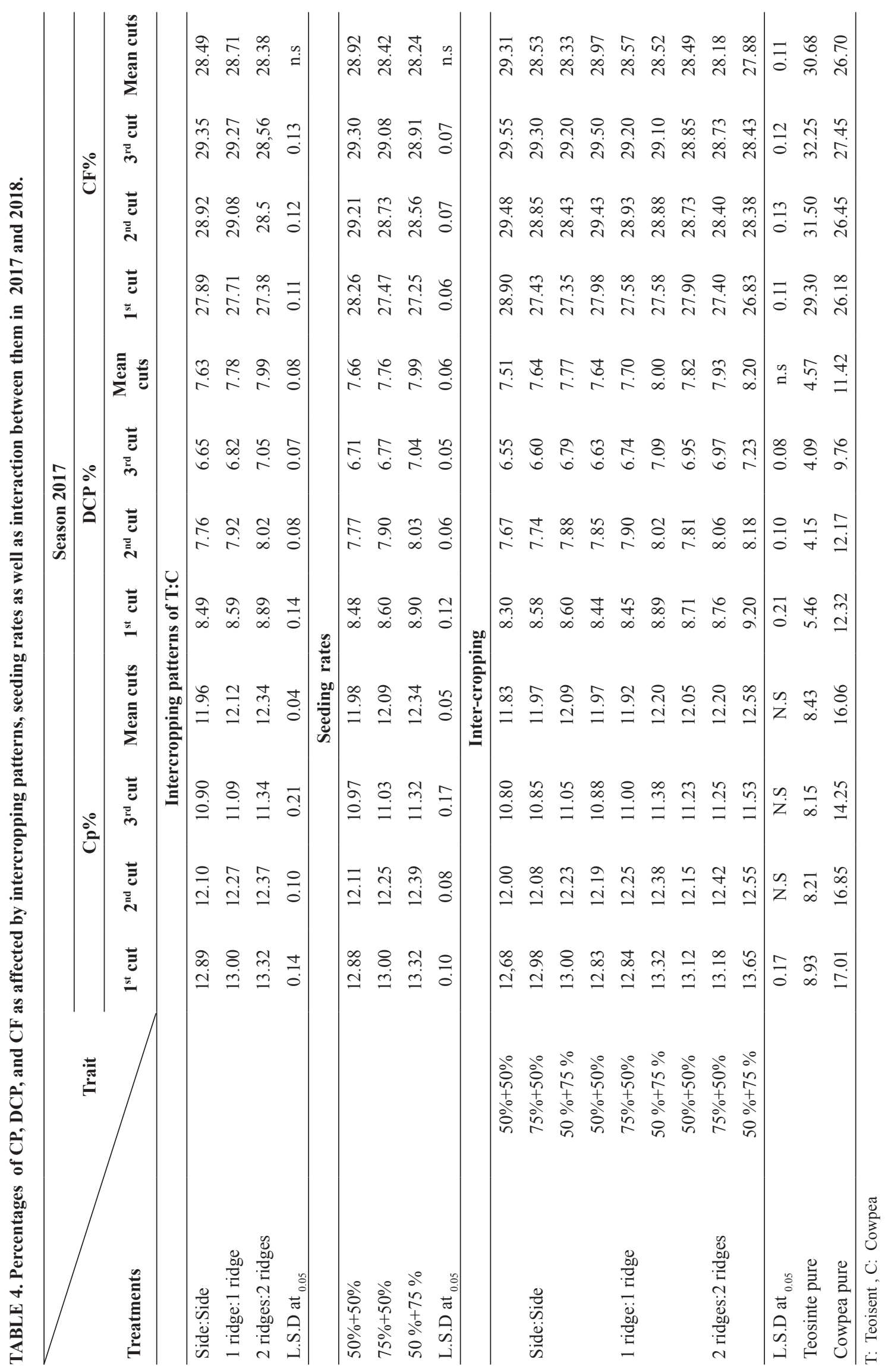

Egypt. J. Agron. 41, № .2 (2019) 


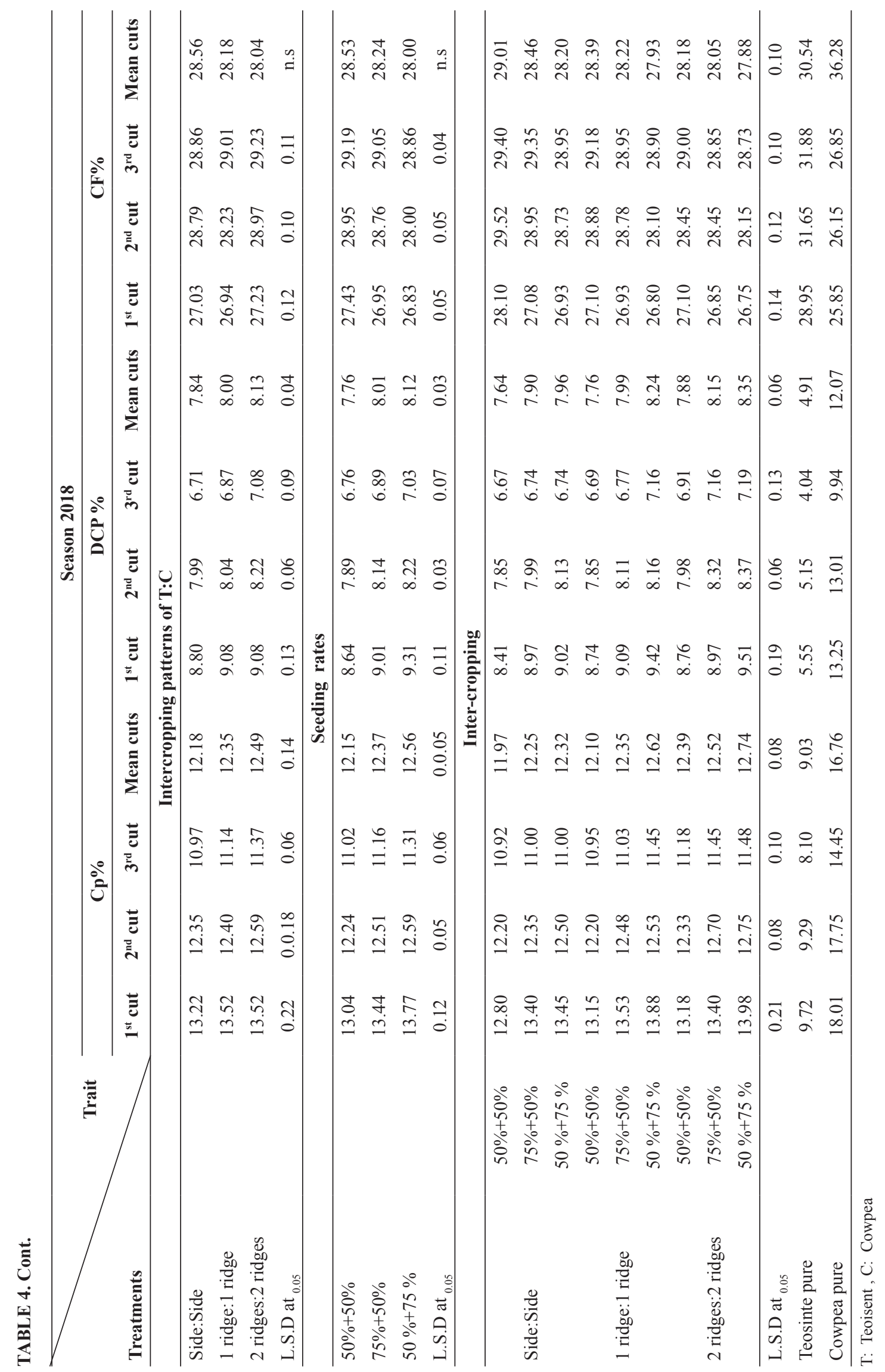

Egypt. J. Agron. 41, No .2 (2019) 
Feeding units (crude protein and digestable crude protein yield)

Effect of intercropping patterns

Data presented in Table 5 reveled that total of crude protein and digestible crude protein yields were significantly affected by different intercropping patterns in both seasons. Data indicated that crude protein and digestible crude protein yields of cowpea pure stand surpassed each of teosinte pure stand and different intercropping patterns (three cuts as well as total yields) in both seasons.

Also, data revealed that 2:2 intercropping pattern was superior in all cuts and total yields for crude protein and digestible crude protein and 1:1 intercropping pattern occupied the second ranking whereas, cowpea intercropped on the other side of teosinte ridges was the lowest one in both seasons. This result may be due to the increase of crude protein and digestible crude protein contents of teosinte and cowpea mixture as a result of symbiotic rhizobial biological functions of legume in fixing and supplying nitrogen to the companion teosinte beside of creating better microenvironment within plant canopies for better growth and quality and thus reflected on the improvement and quality of digestible crude protein.

\section{Effect of seeding rates}

Data presented in Table 5 showed that different seeding rates were significantly affected on all cuts as well as total of crude protein and digestable crude protein yield in both seasons. Data revealed that total of crude protein and digestible crud protein yield were achieved with $75 \%$ teosinte+ $50 \%$ cowpea in both seasons followed by $50 \%$ teosinte $+75 \%$ cowpea and $50 \%+50 \%$ showed the lowest value in both seasons. Also, results indicated that cowpea pure stand recorded the highest value for treatments compared with other different seeding rates treatments and teosinte pure stand. Similar results were obtained by Abd El-Shafy (2002) for crude protein yield Zeidan et al. (2003) for digestible crude protein yield.

\section{Interaction effects}

Data presented in Table 5 indicated that total crude protein and digestible crude protein yields were significantly affected by the interaction between the intercropping patterns and seeding rates in both seasons. Data revealed that cut 2, cut 3 and total yield of crude protein recorded the highest value at 2:2 intercropping pattern with $75 \%+50 \%$ teosinte/cowpea in both seasons. Total crude protein yield were 914.70 and $887.92 \mathrm{~kg}$ $\mathrm{fed}^{-1}$ in the first and second seasons respectively. With respect to digestible crude protein yield $1^{\text {st }}$ cut in both seasons gave the highest value with treatment of 2:2 intercropping pattern and seed rate of $50 \%$ teosinte $+75 \%$ cowpea. Also, data revealed that $2^{\text {nd }}$ cut and $3^{\text {rd }}$ cut achieved the highest values at 2:2 intercropping pattern with $75 \%$ teosinte $+50 \%$ cowpea for these characters in both seasons. In general, total of digestible crude protein gave the highest value $\left(591.19 \mathrm{~kg} \mathrm{fad}^{-1}\right)$ by $75 \%$ teosinte $+50 \%$ cowpea seed rate of its pure stand under 2:2 intercropping pattern in the first seasons ; and $\left(581.51 \mathrm{~kg} \mathrm{fed}^{-1}\right)$ at $50 \%$ teosinte $+75 \%$ cowpea under 2:2 intercropping pattern in the second seasons.

\section{Competitive relationships and yield advantages \\ Land equivalent ratio (LER)}

Land equivalent ratio (LER) was increased than one in all treatments by the interactions between intercropping patterns with seeding rates in the first and second seasons as shown in Table 6 . Results revealed that the increases were ranged from $3 \%$ up to $30 \%$ and $4 \%$ up to $33 \%$ in the first and second seasons, respectively. In all treatment Lt was higher than $\mathrm{L}_{\mathrm{c}}$ except treatments which included $75 \%$ seeding rate of cowpea in the first and second seasons. Data indicated that the highest value was recorded with 2:2 intercropping pattern which included $75 \%$ teosinte $(30 \%$ and $33 \%)$ in the first and second seasons, respectively. On the other hand, the lowest values for LER $(3 \%$ and $4 \%$ ) when cowpea was intercropped on the other side of teosinte ridges by $50 \%$ teosinte $+50 \%$ cowpea seeding rate in the first and second seasons, respectively. Similar results were obtained by Abd EL-Shafy (2002) and Sharawy et al. (2011).

\section{Relative crowding coefficient}

All results which resulted from the interaction between intercropping patterns and seeding rate were achieved yield advantages compared with pure stand of teosinte or cowpea as shown in Table 7. Data revealed that the highest value for $\mathrm{K}$ was achieved when cowpea was intercropped by $50 \%$ with teosinte $+75 \%$ of cowpea seeding rate of its pure stand under 2:2 intercropping patterns (3.89 and 4.89) in the first and second seasons, respectively, and opposite, the lowest value for $\mathrm{K}$ was showed with $50 \%+50 \%$ seed rate for both crops and intercropping cowpea on the other side of teosinte ridges. Similar results were obtained by Abd EL-Shafy et al. (2009) and Reza (2012) 


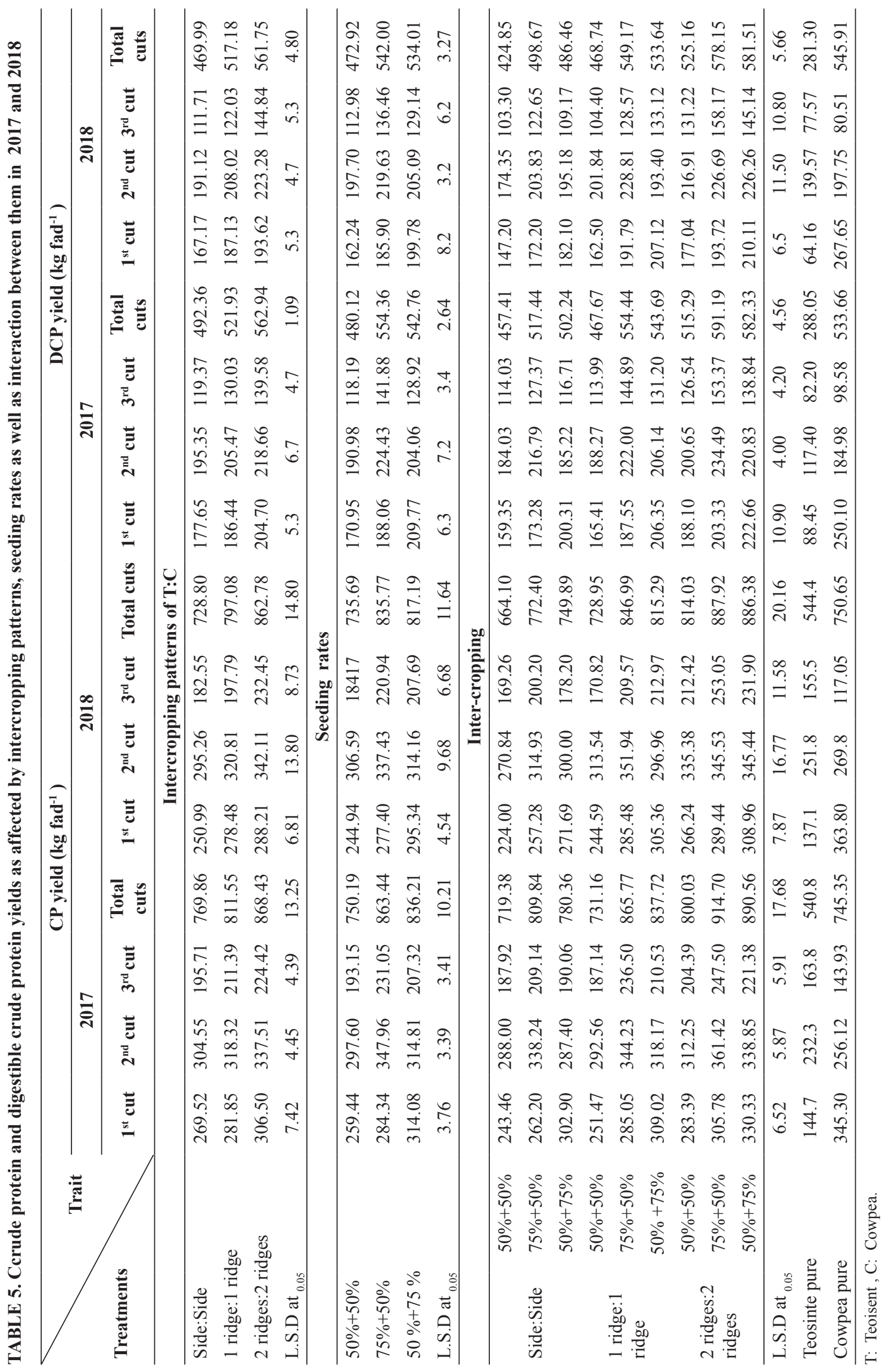


TABLE 6. LER of total forage yield as affected by interaction between intercropping patterns and seeding rates in 2017 and 2018

\begin{tabular}{|c|c|c|c|c|c|c|c|c|c|c|c|}
\hline \multirow{3}{*}{$\begin{array}{l}\text { Treatments } \\
\text { Inter-cropping }\end{array}$} & \multirow{3}{*}{ Characters } & \multicolumn{5}{|c|}{2017} & \multicolumn{5}{|c|}{2018} \\
\hline & & \multicolumn{2}{|c|}{ Total cuts } & \multicolumn{3}{|c|}{ Land equivalent ratio } & \multicolumn{2}{|c|}{ Total cuts } & \multicolumn{3}{|c|}{ Land equivalent ratio } \\
\hline & & $\mathbf{T}$ & $\mathbf{C}$ & $\mathbf{L}_{\mathbf{T}}$ & $\mathbf{L}_{\mathrm{C}}$ & LER & $\mathbf{T}$ & $\mathbf{C}$ & $\mathbf{L}_{\mathrm{T}}$ & $\mathbf{L}_{\mathrm{C}}$ & LER \\
\hline \multirow{3}{*}{ Side:Side } & $50 \%+50 \%$ & 18.0 & 11.0 & 0.56 & 0.47 & 1.03 & 17.0 & 10.5 & 0.56 & 0.48 & 1.04 \\
\hline & $75 \%+50 \%$ & 23.7 & 10.0 & 0.73 & 0.43 & 1.16 & 21.5 & 9.75 & 0.70 & 0.45 & 1.15 \\
\hline & $50 \%+75 \%$ & 17.5 & 14.1 & 0.54 & 0.59 & 1.13 & 16.5 & 13.5 & 0.53 & 0.61 & 1.14 \\
\hline \multirow{3}{*}{1 ridge: 1 ridg } & $50 \%+50 \%$ & 18.5 & 12.0 & 0.57 & 0.52 & 1.09 & 19.0 & 10.8 & 0.63 & 0.50 & 1.13 \\
\hline & $75 \%+50 \%$ & 24.0 & 11.5 & 0.76 & 0.50 & 1.23 & 23.0 & 10.5 & 0.76 & 0.48 & 1.24 \\
\hline & $50 \%+75 \%$ & 18.0 & 15.5 & 0.56 & 0.66 & 1.22 & 18.5 & 13.8 & 0.61 & 0.62 & 1.23 \\
\hline \multirow{3}{*}{2 ridges: 2 ridges } & $50 \%+50 \%$ & 19.5 & 12.5 & 0.60 & 0.54 & 1.14 & 20.5 & 12.0 & 0.68 & 0.55 & 1.23 \\
\hline & $75 \%+50 \%$ & 25.0 & 12.0 & 0.78 & 0.52 & 1.30 & 24.8 & 11.0 & 0.82 & 0.51 & 1.33 \\
\hline & $50 \%+75 \%$ & 18.5 & 16.5 & 0.57 & 0.71 & 1.28 & 20.0 & 14.5 & 0.66 & 0.64 & 1.30 \\
\hline Pure stand & & 32.00 & 23.00 & & & --- & 30.00 & 21.50 & & & $\begin{array}{ll}--- \\
---\end{array}$ \\
\hline
\end{tabular}

T: Teoisent, C: Cowpea.

TABLE 7. Relative Crowding Coefficient ( RCC) of total forage yield as affected by interaction between intercropping Patterns and seeding rates in 2017 and 2018

\begin{tabular}{lccccccc}
\hline & \multirow{2}{*}{ Characters } & \multicolumn{3}{c}{$\mathbf{2 0 1 7}$} & \multicolumn{3}{c}{$\mathbf{2 0 1 8}$} \\
\cline { 3 - 8 } Treatments & & \multicolumn{2}{c}{$\begin{array}{c}\text { Relative crowding } \\
\text { coefficient }\end{array}$} & \multicolumn{2}{c}{ Relative crowding coefficient } \\
\cline { 3 - 8 } & & $\mathbf{K}_{\mathbf{t}}$ & $\mathbf{K}_{\mathbf{C}}$ & $\mathbf{K}$ & $\mathbf{K}_{\mathbf{t}}$ & $\mathbf{K}_{\mathbf{C}}$ & $\mathbf{K}$ \\
\hline \multirow{3}{*}{ Side:Side } & $50 \%+50 \%$ & 1.28 & 0.91 & 1.16 & 1.30 & 0.95 & 1.23 \\
& $75 \%+50 \%$ & 2.76 & 0.76 & 2.09 & 2.52 & 0.82 & 2.06 \\
& $50 \%+75 \%$ & 2.05 & 1.48 & 3.03 & 1.22 & 1.68 & 2.04 \\
\hline \multirow{3}{*}{1 ridge:1 ridg } & $50 \%+50 \%$ & 1.28 & 1.09 & 1.39 & 1.72 & 1.00 & 1.72 \\
& $75 \%+50 \%$ & 3.00 & 1.00 & 3.00 & 3.28 & 0.95 & 3.11 \\
& $50 \%+75 \%$ & 1.28 & 2.06 & 2.63 & 1.60 & 1.68 & 2.68 \\
\hline \multirow{3}{*}{ ridges:2 ridges } & $50 \%+50 \%$ & 1.58 & 1.19 & 1.88 & 2.15 & 1.26 & 2.70 \\
& $75 \%+50 \%$ & 3.57 & 1.89 & 3.89 & 4.71 & 1.04 & 4.89 \\
& $50 \%+75 \%$ & 1.37 & 2.53 & 3.46 & 2.00 & 2.07 & 4.14 \\
\hline
\end{tabular}

Aggressivety (A)

Results in Table 8 indicated that teosinte was the dominant crop in 6 treatments and was dominated in 3 treatments out of 9 treatments in both seasons. $A_{t}$ vlue was positive when cowpea was intercropped with teosinte by $50 \%$ seeding rate of its pure stand. On other hand. $A_{C}$ value was positive when cowpea was intercropped with teosinte by $75 \%$ seeding rate of its pure stand. Similar results were obtained by Abd ELShafy et al. (2009) and Hassan et al. (2017).

\section{Conclusion}

From the previous results could be concluded that intercropping cowpea with teosinte at 2:2 intercropping pattern and using $75 \%$ teosinte $+50 \%$ cowpea seeding rate of its pure stand to maximize forage production and good quality as well as Land use efficiency.

It could be concluded that to obtain the best forage production and good quality fodder and increasing Land use efficiency in summer season must be planting $15 \mathrm{~kg}$ teosinte $+10 \mathrm{~kg}$ cowpea seeding rates/fed $(75 \%+50 \%)$ under $2: 2$ intercropping pattern in alternating ridges. 
TABLE 8. Aggressivity of total fresh yield as affected by intercropping patterns and seeding rates in 2017 and 2018 seasons.

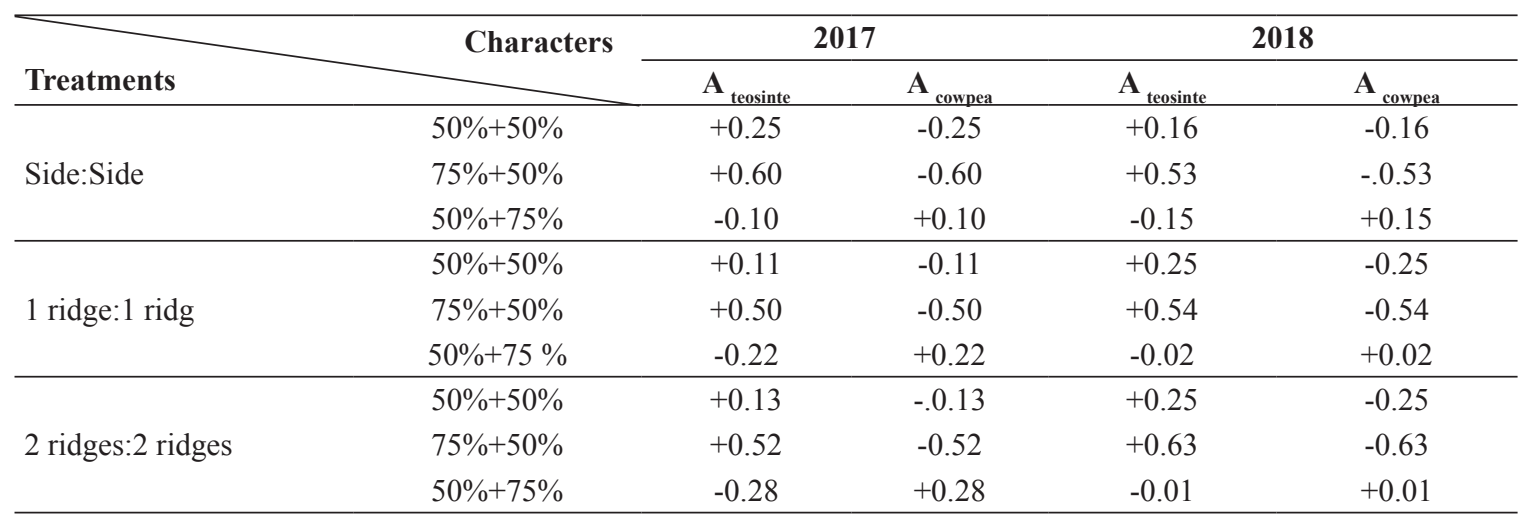

\section{References}

Abd El-Shafy, A.S. (2002) Intercropping teosinte with guar under different plant population densities. Fayoum J. Agric, and Dev. 16(2), 91-97.

Abd El-Shafy, A.S., Tarrad, M.M. and Fahmy, A.H. (2009) Effect of intercropping patterns of teosinte with cowpea on yield, quality and their competitive relationships. Ann of Agric. Sci., Moshtohor, 47(3), 215-224.

Abraha, L. (2013) The effect of intercropping maize with cowpea And lablab on crop yield. Her. J. Agric. Food Sci. Res. 2(5), 156-170.

A.O.A.C. (2000) "Official Methods of Analysis",17 $7^{\text {th }}$ Ed. Association of Official Analytical Chemists, Washington, DC, USA.

Churach, D.C. (1979) "Livestock Feeds and Feeding" $4^{\text {th }}$ ed. pp 79.0 \& Books Inc; Corallis, Dragon 97330, U.S.A.

Dahmardeh, M.A., Ghanbari, B.S. and Ramroudi, M. (2009) Effect of intercropping maize with cowpea on green forage yield and quality evaluation. Asian Plant Sci. 8(3), 235-239.

De-Wit, C.T. (1960) On comperition versug landBouwkudige Onder Zoek, 66(8), 1-82.

Eskadari, H. (2012) Yield and quality of forage produced inintercropping of maize (Zea mays) with cowpea (Vigna sinensis) and mungbean (Vigna radiate) as double cropped. J. Basic Appl. Sci. Res. 1, 93-97.

Hamdollah, E.A. and Ahmad, G. (2009) Intercropping of maize (Zea mays) and cowpea (Vigna sinensis) as whole-crop forage: Effect of different planting pattern on total dry matter production and maize forage quality. Not. Bot. Hort. Agrobot. Cluj. 37(2) 152-155.

Hassan, H.H.M. (2003) Studies on some forage mixtures. M.Sc. Thesis, Fac. Agric. Zagazig Univ., Egypt.

Hassan, H.H.M., Sayed, Mervat R.I. and Mousa, Walaa M.E. (2017) Effect of intercropping on forage yield and land use efficiency of some summer fodder crops. Zagazig J. Agric. Res. 44(6A), 2007-2020.

Hymowitz, T.F., Collins, P. and Walker, W.M (1972) Relationship between the content of oil, protein and sugar un soybean seed. Agron. J. 64, 613-616.

Javanmard, A., Mohammadi-Nasab, A.D., Javanshir, A., Moghaddam, M. and Janmohammadi, H. (2009) Forage yield and quality in intercropping of maize with different legumes as double- cropped. J. Food Agric Enviro. 7(1), 163-166.

Lal, M., Relwainy, L.L. and Singh, J.P. (1980) Influence of cutting management and nitrogen fertilization on forage yield and regeneration of teosinte. Forage Res. 6(1), 99-102.

Maurice, G., Albert, N., Isidor, T. and Francois, A.A (2010) Altering the time of intercropping cowpea (Vibna unguiclata L. Walp.) relative to maize (Zea mays L.): A food production strategy to increase crop yield attributes in Adamawa-Camroon. World J. Agric. Sci. 6, 473-479.

Mc-Gilchrist, C.A. (1965) Analysis of competition experiments. Biometrics, 1, 975-985. 
Norman, L.M. and Jarvis, P.G. (1975) Photosynthesis in Sitka spruce [Picea sitchensis (Bong.) Carr.] III. Measurements of canopy structure and interception of radiation. J. Appl. Ecol. 12, 839-878.

Papastylianou, I. (2004) Effect of rotation system and $\mathrm{N}$ fertilizer on barley and common vetch grown in various crop combinations and cycle lengths. J.Agric. Sci. 142, 41-48.

Reza, Z.O. (2012) Evaluation of quantitative and qualitative traits of forage sorghum and lime bean under different nitrogen fertilizer regimes in addititive-replacement series. Int. J. Agric. Sci. 4, 223-238.

Sarhan, G.M. and Atia, A.A. (2000) Study the behavior of some fodder cpwpea (Vigna sinensis L. Walp) cultivar mixed with teosinte (Euchlaena Mexicana) on forage production and nutritive quality. Asssiut J. Agric.Sci. 31(1), 195-205.

Sharawy, Wafaa M., Helmy, Amal A. and Abd El Shafy, A.S. (2011) Intercropping teosinte with cowpea or guar and their effects on forage yield, quality and competitive relationships. Egypt. J. Appl. Sci. 26 (4), 284-295.

Snedecor, G.W. and Cochran, W.G. (1981) "Statistical Methods" Oxford and IBH. Puplishing G. $6^{\text {th }}$ ed., pp. 299-310.

Steel, R.G.D. and Torrie, J.H. (1980) "Principles and Procedures of Statistics". Mc. Grow- Hill Book Co.Inc., New York.

Willey, R.W. (1979) Intercropping its importance and research needs 1 . Competition and yield advantage and 2. Agronomy and research approaches. Field Crop Abstracts, 32, 73-85.

Zeidan, E.M., Ramadan, I.E., Gomaa, M.A. and Hassan, H.H.M. (2003) Effect of sowing date, mixture pattern and cutting date on forage yield productivity of fodder maize, cowpea and guar. Zagazig J. Agic. Res. 30, 1311-1326.

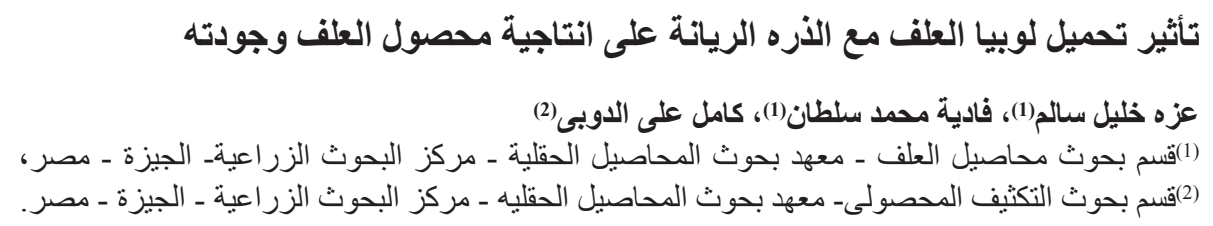

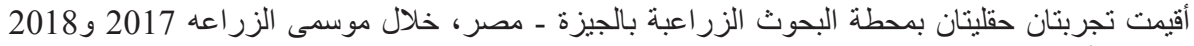

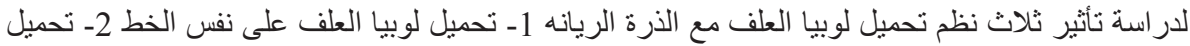

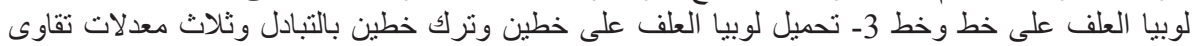

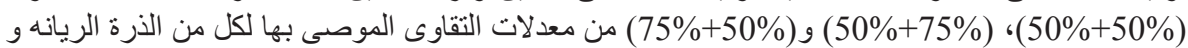

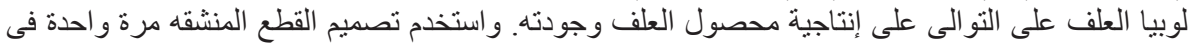

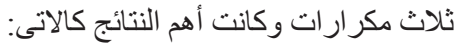

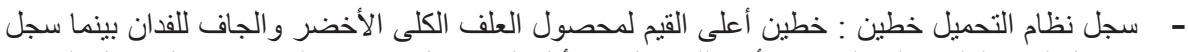

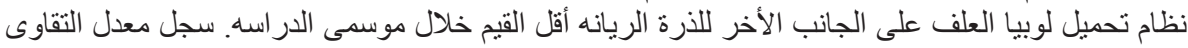

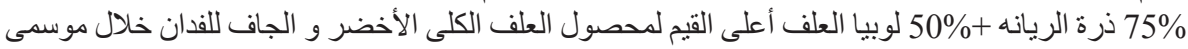

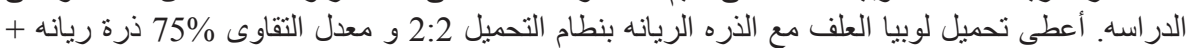

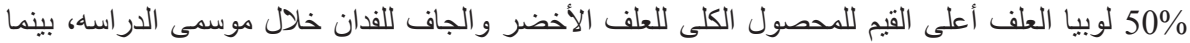
زر اعة لو بيا العلف على الجانب الأخر لخطوط الذره الريانه مع معدل التقاوى 50\% لكلا المحصولين أقل القيم خلال موسمى الدر اسة. - زاد محتوى البروتين و النسبة المئويه للبروتين المهضوم وكذللك محصول الفدان للبروتين الخام و البروتين

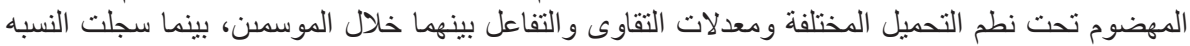

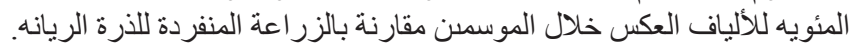

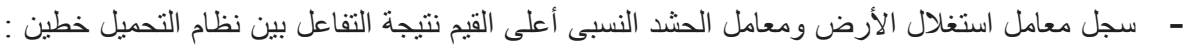

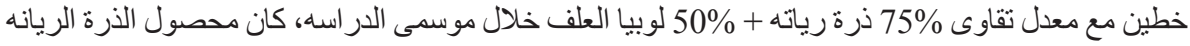

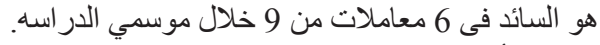

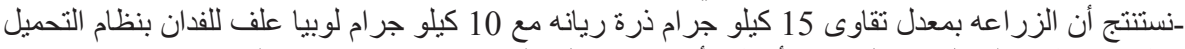

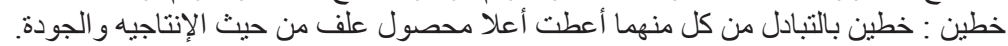

